\title{
AGRONEGÓCIO DO DENDÊ E CAMPESINATO NO PARÁ
}

Rafael Benevides de Sousa ${ }^{1}$ Cátia Oliveira Macedo²

Resumo: A expansão capitalista do dendê pelo nordeste do Pará, no início do século XXI, está intrinsecamente conectada com os rumos políticos do governo de Luís Inácio Lula da Silva, em 2003, quando se intensifica o investimento na produção dos agrocombustíveis no Brasil. Articulam-se neste cenário o discurso de preservação e desenvolvimento regional, aliados a inclusão social dos camponeses na cadeia produtiva do dendê. Contraditoriamente à perspectiva de geração de renda e, por conseguinte, melhoria de vida dos povos do campo expresso no PNPB, visualizou-se a ampliação das disputas entre terra de negócio versus terra de trabalho. Desse modo, busca-se nesse artigo discutir a espacialização do agronegócio do dendê no nordeste paraense bem como as ações empreendidas pelos camponeses como estratégia de resistência a esse processo. $O$ texto foi construído a partir das reflexões suscitadas na pesquisa de campo realizada entre os anos de 2012 e 2017 na região. Mais especificamente, apresentaremos uma abordagem geo-histórica do dendê na Amazônia e suas relações contraditórias com as famílias camponesas que vivem em suas proximidades.

Palavras-chave: Campesinato. Agronegócio. Dendê. Pará. Amazônia.

\section{AGRIBUSINESS OF THE OIL PALM AND PEASANTS IN THE PARÁ}

Abstract: The capitalist expansion of dendê palm agriculture in northeastern Pará at the beginning of the 21st century is utterly linked to the political trends of Luís Inácio Lula da Silva's government in 2003, when the investment in the production of agro fuels in Brazil mounted. The discourse concerning regional preservation and development, connected with the social inclusion of peasants in the dendê palm production chain, were jointed in this scenario. In contrast to the prospect of income flowing and, consequently, the improvement of the life of the countryside people expressed in the PNPB, there was the expansion of disputes between agribusiness and land of peasant labor. Thus, this article aims to discuss the spatial spreading of dendê palm business in northeastern Pará State as well as the actions strategically undertaken by peasants to resist this process. The text was based on the analyses derived from the field research carried out between 2012 and 2017 in the region. More specifically, we present a geo-historical approach to dendê palm farming in the Amazon and its contradictory relations with the peasant families living in its vicinity.

Keywords: Peasantry. Agribusiness. Oil Palm. Pará. Amazonia.

\section{EL AGRONEGOCIO DEL DENDÊ Y EL CAMPESINADO EN PARÁ}

Resumen: La expansión capitalista de la agricultura de palma de dendê en el noreste de Pará, a principios del siglo XXI, está totalmente vinculada a las tendencias políticas del gobierno de Luís Inácio Lula da Silva, en 2003, cuando

\footnotetext{
${ }^{1}$ Universidade Federal do Sul e Sudeste do Pará, Instituto de Estudos do Trópico Úmido, Xinguara/PA, Brasil, benevidessousa@gmail.com, https://orcid.org/0000-0001-6084-2486

2 Universidade do Estado do Pará, Centro de Ciências Sociais e Educação, Belém/PA, Brasil, ccatiammacedo@gmail.com, https://orcid.org/0000-0002-4318-6234
} 
creció la inversión en la producción de agro combustibles en Brasil. El discurso sobre la conservación y el desarrollo regional, relacionado con la inclusión social de los campesinos en la cadena de producción de la palma de dendê, se fortaleció en este escenario. En contraste con la perspectiva del flujo de ingresos y, en consecuencia, la mejora de la vida de las personas del campo expresada en el PNPB, hubo una expansión de las disputas entre agro negocio y la tierra de trabajo campesino. Por lo tanto, este artículo pretende discutir la expansión espacial del negocio de la palma de dendê en el noreste del estado de Pará, así como las acciones emprendidas estratégicamente por los campesinos para resistir a este proceso. El texto se basó en los análisis derivados de la investigación de campo realizada entre 2012 y 2017 en la región. Más específicamente, presentamos un enfoque geo histórico sobre el cultivo de la palma de dendê en el Amazonas y sus relaciones contradictorias con las familias campesinas que viven en sus alrededores.

Palabras clave: Campesinado. Agro negocio. Dendê. Pará. Amazonia.

\section{Introdução}

A expansão capitalista do dendê pelo nordeste do Pará, no início do século XXI, está intrinsecamente conectada com os rumos políticos do governo de Luís Inácio Lula da Silva, em 2003, quando se intensifica o investimento na produção dos agrocombustíveis no Brasil que, em dose homeopática, misturar-se-ia aos combustíveis fosseis.

A partir de então, a produção de "combustíveis limpos" consolidou-se na agenda das políticas públicas ligadas a questão energética, ao mesmo tempo disseminando pelas regiões brasileiras as potencialidades e as "vocações" geográficas dentro da cadeia produtiva da palma. Essa opção produtiva do Estado brasileiro gerou consequências para as populações do campo, materializadas principalmente no aumento da pressão sobre os territórios das populações campesinas, quilombolas e indígenas.

Para o capital os territórios das populações camponesas e indígenas não passam de riquezas a serem incorporadas a sua dinâmica de reprodução. Da mesma forma o Estado, para quem, esses territórios são concebidos, como ativo ambiental, a serviço do desenvolvimento e modernização do país. Como resultado dessa aliança, elege-se o agronegócio como estratégia de desenvolvimento para o campo brasileiro.

O agronegócio modernizou o agroextrativismo mantendo a lógica colonial da dominação e subordinação. O agroextrativismo é parte do agronegócio, com destaque para dois sistemas que estão na sua base: a agricultura e a pecuária. É a partir desses sistemas que o agronegócio se apropria e extrai os recursos naturais. Este setor primário da economia tem recebido cada vez mais investimentos para a produção de alimentos, fibras e, nas últimas décadas, para a produção de energia, através dos agrocombustíveis, o que intensificou a territorialização do capital internacional por diversos países à procura de terras (FERNANDES, 2017, p. 95-96). 
Dentro desse processo enunciado por Fernandes (2017), o sistema agroextrativista moderniza-se, contudo, ainda pautado no mesmo critério colonial.

A ideia de extração refere-se aos processos produtivos renováveis e não renováveis, de modo que a agricultura - por seu potencial renovável e de expansão - tornou-se atraente para diferentes tipos de investidores. $O$ agroextrativismo também significa a separação dos sistemas do agronegócio em escala internacional, o que significa dizer que extrai os recursos em um país, exporta e industrializa em outro, mantendo, assim, o processo de colonização e, portanto, de dominação territorial, portanto, dominação política e econômica (FERNANDES, 2017, p. 96).

Essa preferência pelo sistema agroextrativista é observada por Gudynas (2009) numa análise sobre os países Sul-americanos.

También se debe señalar que, especialmente en Argentina, Brasil y Uruguay, se ha alentado un cambio sustancial en la agricultura orientándola a monocultivos de exportación. Estas nuevas prácticas representan un extractivismo agrícola. Se la observa especialmente en el cultivo de soja, basado en variedades transgénicas, alto uso de maquinarias, herbicidas químicos, escaso o nulo procesamiento, y exportación como commodity. Son prácticas que se han expandido y reforzado con el beneplácito, e incluso apoyo, de las administraciones Kirchner, Lula da Silva y Vázquez. Otro tanto sucede con los monocultivos forestales, que cubren amplias superficies, y están volcados a elaborar pasta de celulosa. Por lo tanto, el extractivismo goza de buena salud bajo el progresismo, y en algunos casos se ha acentuado (GUDYNAS, 2009, p. 191-192).

$\mathrm{Na}$ América Latina, governos se alinham política e economicamente com as formas mais perversas de exploração dos recursos da natureza, e que tem como consequência, em muitas situações a desagregação ou a constituição de tensões nos territórios e populações que sobrevivem dessa natureza.

Nessa lógica desenvolvimentista, são reforçados alguns estigmas do subdesenvolvimento que vão legitimar a ação do capital como um mecanismo para alcançar a modernidade, para o qual as populações campesinas, indígenas e quilombolas são consideradas um empecilho para o progresso regional e, portanto, da nação.

O mercado de terras que vai se estabelecer nos municípios envoltos com o cultivo do dendê, demarca o campo de tensões que se estabelece na região a partir de então. Rapidamente são negociadas desde antigas fazendas improdutivas até propriedades camponesas, afirmando, assim, um campo em disputa.

Tudo venderam, não existe terra, só é dendezal, no ramal é só dendê, não existe mandioca. Quando você vê um terreno com mandioca, pimenta, é o pessoal que zelam pela terra e que não venderam. Tu sabe quem trouxe esses projetos pra cá, pra Concórdia, pro Acará e tudo? Foi puxado pelo PT, mas o principal foi o Lula. Ele falava muito no biodiesel, lembra? O Elias, que era muito ligado com ele, trouxe esse plano pra cá. Mas o dendê, isso é uma indústria que cresce, mas não cresce pro pequeno que foi feito pra trabalhar pra firma. Quando tu tá no teu serviço, tu tá trabalhando pra ti, quando tu tá trabalhando pra empresa, tu tá trabalhando pra empresa. Então o dendê tem empresa que é do Pará, a Agropalma é do Pará, a 
Biopalma é do Pará, mas tem empresa que é de fora. Que a Amazônia é olhada com os olhos oh, mas não é pra preservar. Eu escutei no jornal que tinha um país aí que tava ajudando pra evitar a desmatação da Amazônia, mas como a devastação tá avançando, ela cortou a metade do dinheiro que era pra prevenir a desmatação. O Brasil não tem jeito mesmo, nós fomo colônia e de colônia não passa, só é mandado pelos outros. (M. N., Comunidade KM 35, Concórdia do Pará, 12 de abril de 2017).

Esse depoimento demonstra que a expansão do agronegócio do dendê tem agido na tentativa da homogeneização da paisagem em um contínuo "dendezal", expropriando o campesinato que se construiu histórica e geograficamente pelos igarapés-rios e estradas no nordeste paraense. Porém, há clara resistência, os camponeses teimam em continuar a viver no campo, mesmo que cercados pela oleaginosa. Para M. N.: "é o pessoal que zelam pela terra e que não venderam."

Esse antagonismo entre as populações agrário-extrativista e os agentes capitalistas nem sempre aparece como mera oposição. Vislumbram-se, também, diálogos e coexistências, especialmente, nas relações comerciais e de trabalho que cooperam nos processos de recriação do campesinato, mesmo quando a função do capital é expropriá-los de suas terras e dos meios de produção.

Desse modo, buscamos nesse artigo realizar uma discussão acerca da espacialização do agronegócio do dendê no nordeste paraense e o movimento de resistência da agricultura camponesa em face dessa frente de expansão do capital.

O texto foi construído a partir das reflexões suscitadas na pesquisa de campo realizado entre os anos de 2012 e 2017 no nordeste do Pará. Mais especificamente, apresentaremos uma abordagem geo-história do dendê na Amazônia e suas relações contraditórias com as famílias camponesas que vivem em suas proximidades.

\section{A conformação territorial do agronegócio do dendê e a agricultura camponesa no nordeste paraense}

O contexto histórico de ocupação do nordeste paraense desencadeou uma dinâmica territorial que o diferencia em alguns aspectos do restante da Amazônia. Considerada como uma região de ocupação consolidada, notamos que essa parte do Pará é compreendida por uma estrutura fundiária de demarcação mais antiga, passando pelo sistema de sesmarias, colônias agrícolas e ocupação espontânea de posseiros, quilombolas e indígenas, além dos atuais processos de regularização fundiária. 
Partindo da perspectiva da existência de várias Amazônias (GONÇALVES, 2010), entende-se a região, como uma diversidade territorial compreendida por uma dinâmica regional influenciada por diferentes territórios, mediante a abrangência e a consolidação do capital. Assim, teremos na Amazônia territórios de influência da mineração, dos complexos hidrelétricos, da exploração extrativista (seringa, castanha, açaí e pescado), da agropecuária (soja, eucalipto, dendê e gado) e, atualmente, dos latifúndios genéticos na lógica capitalista do carbono (GONÇALVES, 2012).

Para delinear o desenvolvimento regional, a partir do ano 2000, o nordeste paraense torna-se palco de mais um empreendimento para a Amazônia, materializado na expansão do monocultivo do dendể ${ }^{3}$. O governo do estado do Pará (2011-2018), espera com a produção da oleaginosa sanar essa suposta estagnação econômica e possibilitar a recuperação de áreas desmatadas, criando mecanismos de desenvolvimento dentro de metas sustentáveis

A introdução do cultivo do dendê na Amazônia data das décadas de 1940 e 1950, no Estado do Pará, a partir do cultivo de sementes subespontâneas vindas do estado da Bahia, por intermédio do antigo Instituto Agronômico do Norte (IAN), atual EMBRAPA. Nos anos seguintes, diversos estudos técnicos ${ }^{4}$ abordam a viabilidade agro-econômica de projetos destinados ao cultivo de dendezais pelo interior do Pará, para os quais o IAN e o SPVEA destacam-se como os principais agentes promotores da expansão da palma na Amazônia.

Em 1965, a assinatura do acordo entre a SPVEA/SUDAM e o IRHO 5 (Instituto de Pesquisa de Óleos e Oleaginosas - França) cria a possibilidade de parcerias em escalas comerciais por meio de convênios entre empresas privadas e órgãos estatais. Um dos principais exemplos desse contexto foi a pareceria entre a

3 "O dendê aportou ao Brasil no século XVI e se adaptou muito bem ao litoral do sul da Bahia; de origem africana a palmeira Elaeis guineensis enraíza-se ao estado do Pará pelo município de Benevides em $1968 \mathrm{com}$ a experiência do primeiro plantio comercial. Desta palma são extraídos dois óleos: o retirado da polpa ou mesocarpo; e o óleo de palmiste, que vem da amêndoa ou endosperma" (CARVALHO; NAHUM, 2014, p. 19).

${ }^{4}$ Entre os estudos pioneiros sobre o cultivo do dendê na Amazônia, destacam-se: PIRES, J. M. Algumas palmeiras oleaginosas. Norte Agronômico, Belém, PA, v. 1, n. 1, p. 21-33, nov. 1953; ADDISON, G. O. \& PIRES, J. M. Considerações relativas à sistemática de algumas plantas úteis. Norte Agronômico, Belém, PA, v. 3, n. 3, p. 21-26, jul. 1957; CONDURU, J. M. P. Notas sumárias sobre a cultura do dendê na Amazônia. Belém, PA: Instituto Agronômico do Norte, 1957. p. 24; OLLAGNIER, M.; MARIA-SUBE, C. Relatório sobre as oleaginosas no Brasil: pesquisa agronômica e possibilidade de desenvolvimento. Rio de Janeiro: Instituto de Óleos, 1961. p.198.

5 "Por volta de 1950 um amplo programa de pesquisa foi desenvolvido pelo Institut de Recherches Pour Lês Huiles et Les Oleagineux - IRHO em parceria entre o governo brasileiro, representado pelo Ministério da Agricultura, e o governo francês, representado pelo IRHO, a fim de identificar em todo o território brasileiro áreas com as melhores condições edafoclimáticas para o desenvolvimento do cultivo do dendê em escala agroindustrial" (CARVALHO; NAHUM, 2014, p.19). 
SUDAM, o Grupo Ovídio Miranda Brito (atual Denpasa) e pequenos produtores rurais no plantio de 3 mil hectares de dendê no município de Benevides (atual Santa Bárbara) (HOMMA, 2016). Observamos já neste contexto a introdução da agricultura camponesa na cadeia produtiva do dendê.

Até a década de 1970, os projetos direcionados ao plantio de dendê tinha participação ativa de órgãos governamentais. Contudo, em 1972, o Ministério do Interior ordena a transferência do plantio de dendezeiros da SUDAM para a iniciativa privada (CARVALHO; NAHUM, 2014; HOMMA, 2016). Ainda nessa década, observa-se, em nível mundial, a transferência do eixo produtivo de óleo de dendê da África para os plantios racionalizados na Ásia. Devido à elevada demanda internacional da oleaginosa e ao aparecimento de anomalias como o Guia Podre e o Amarelamento Fatal $(\mathrm{AF})^{6}$ nos plantios do dendê, na década de 1980 , cria-se o Programa Nacional de Pesquisa do Dendê, e o antigo Centro Nacional de Pesquisa de Seringueira na Amazônia passa a ser denominado de Centro Nacional de Pesquisa de Seringueira e Dendê, destacando a importância da palma nos planos de desenvolvimento regional (CARVALHO; NAHUM, 2014; HOMMA, 2016).

Apesar da produção do dendê ter sido transferida para a responsabilidade produtiva do setor privado, o desenvolvimento agroindustrial da oleaginosa no Pará continuou nas mãos do Estado. A Embrapa ficou na incumbência da pesquisa agronômica; a SUDAM, com a análise e viabilidade dos projetos; e o BASA e o Banco do Brasil, com o financiamento para a monocultura da palma (CARVALHO; NAHUM, 2014).

Na década de 1980, o dendê avança pela região Guajarina, chegando aos municípios do Acará e Moju, por meio das empresas Denpasa e Agropalma, respectivamente. No município de Santo Antônio do Tauá é criada a Fundação Dendê do Tauá S.A. (Dentauá), em 1982 (CARVALHO; NAHUM, 2014; HOMMA, 2016).

Observa-se até 1985, significativa participação de pesquisadores da Embrapa nos estudos do dendê na Amazônia. Após essa data a pesquisa sobre a

\footnotetext{
6 "AF [Amarelecimento Fatal] é uma ameaça ao desenvolvimento da dendeicultura no Pará, agravada pelo fato de sua causa ser de origem desconhecida. Em decorrência da alta incidência de plantas mortas pelo $\mathrm{AF}$, as pesquisas sobre a doença amarelecimento fatal do dendezeiro se iniciaram em 1986, quando então foi assinado um convênio entre a Associação dos Produtores de Dendê do Pará e Amapá (Aproden) e o governo brasileiro, por meio da Embrapa, no sentido de realizar pesquisas multidisciplinares para o melhor conhecimento do problema e solução do mesmo. Entretanto, em virtude da escassez de recursos financeiros, as pesquisas foram interrompidas em 1991 e reiniciadas somente anos depois. Vários trabalhos foram realizados com o objetivo de determinar a causa ou agente causal do AF do dendezeiro. Entretanto, não foi encontrada ainda nenhuma correlação com insetos, problemas fisiológicos, solo e patógeno" (BOARI, 2008, p. 14).
} 
produção da palma entra em declínio, voltando a ocupar os pesquisadores após o ano de 2000, com o PNPB e o lançamento do programa de Produção sustentável de palma de óleo no Brasil (PSPOB) ${ }^{7}$, em 2010 (HOMMA, 2016).

Na década de 1990, aproximadamente 400 hectares de cultivo do dendê da empresa Denpasa são afetados pelo Amarelecimento fatal, tornando-se um dos principais problemas enfrentados no cultivo da oleaginosa. Ainda na mesma década, são realizados workshops e encontros técnicos para debater a doença conhecida como amarelecimento fatal, e discutir a viabilidade de novos projetos para a Amazônia, como a criação do Grupo de Estudos de Propostas Estratégicos (GEPE), enfatizando a expansão do cultivo do dendezeiro pelo governo do estado do Pará, em 1997 (HOMMA, 2016, p. 31).

No início do século $X X I$, intensifica-se e diversifica-se a produção de alimentos, cosméticos e agrocombustível ${ }^{8}$ a partir do óleo extraído do dendê. Influenciado por uma geopolítica internacional sobre o meio ambiente (mas não exclusivamente por isso), em 2005, o governo brasileiro criou o Programa Nacional de Produção e Uso de Biodiesel (PNPB), com o intuito de gerar um combustível menos poluente a partir de fontes de energia renováveis, no caso o biodiesel.

\begin{abstract}
O biodiesel é um agrocombustível derivado de diferentes fontes oleaginosas como a mamona, palma azeiteira (dendê), algodão, milho, gordura animal, girassol e soja, esta última responsável por $95 \%$ do biodiesel produzido. Enquanto o projeto de produção de álcool é operacionalizado atualmente pela iniciativa privada, a produção de biodiesel se realiza no PNPB (Programa Nacional de Produção e Uso de Biodiesel) e conta com importante participação estatal na sua realização. Governos estaduais também têm feito gestão e investimento para a produção de biodiesel na pequena agricultura (FABRINI, 2010, p. 77).
\end{abstract}

O PNPB na lógica desenvolvimentista do Estado, apresenta como diretrizes a implantação de um programa sustentável, promovendo a inclusão social; garantindo preços competitivos, qualidade e suprimento, e produzindo um biodiesel

\footnotetext{
7 "O Programa Federal de Produção Sustentável de Óleo de Palma (PSOP) foi anunciado no dia 6 de maio de 2010, no município de Tomé-Açú, no Pará. Segundo o Governo Federal, é um programa ambicioso para a expansão do cultivo do óleo de palma (azeite de dendê) na Amazônia e no Nordeste brasileiro. O Programa identificou 31,8 milhões de hectares adequados ao cultivo de óleo de palma (a produção mundial atualmente ocupa 12 milhões), sendo que 29 milhões estão na Amazônia Legal e 2,8 milhões no Sudeste e Nordeste. As áreas são também regiões com forte presença da agricultura familiar. A proposta do programa é oferecer condições para que os investidores incorporem estes agricultores como parceiros" (DROUVOT; DROUVOT, 2012, p. 2).

${ }^{8} \mathrm{Em} 13$ de março de 2002, Agropalma inaugura a primeira fábrica de margarina a partir do óleo de dendê, com capacidade de 4 mil toneladas/ mês, localizada em Belém. Seus produtos são voltados para o mercado de food service. As cinco agroindústrias (Crai, Agropalma, Agropar, Amapalma e CPA) e a Cia Refinadora da Amazônia passam a compor o Grupo Agropalma, constituindo, assim, o maior e mais moderno complexo agroindustrial de plantio de palma, produção e processamento de óleo de palma do País (HOMMA, 2016, p. 33).
} 
a partir de diferentes fontes oleaginosas, fortalecendo as potencialidades regionais para a produção de matéria-prima (SAF-BIODIESEL, 2017).

Nessa perspectiva, com o PNPB é lançado um "novo" ciclo de desenvolvimento no Brasil pautado no discurso ideológico da sustentabilidade e influenciado pelos acordos do clima. Desse modo, notamos que a intenção do governo brasileiro está pautada na geração de um combustível menos poluente, como alternativa ao petróleo, além de diminuir a pobreza e contribuir para a preservação do meio ambiente, respeitando, assim, os acordos e as resoluções climáticas.

Uma das metas do PNPB é a introdução da agricultura camponesa na cadeia produtiva do biodiesel. A partir da criação do Selo Combustível Social, ficou estabelecido que na Amazônia a empresa produtora do biodiesel deve ter, obrigatoriamente, um percentual mínimo de $15 \%$ da matéria-prima provinda do pequeno produtor rural.

Pela primeira vez, a agricultura camponesa foi incluída em um programa de produção através de uma política nacional. Este é o item do PNPB denominado "competitividade e inclusão social" com a criação do "Selo Combustível Social", que isenta do Imposto sobre Produtos Industrializados (IPI), concedido pelo Ministério do Desenvolvimento Agrário (MDA). Esta política foi elaborada a partir da lógica da "integração" um dos princípios dos parâmetros do paradigma do capitalismo agrário. O subsídio que o governo oferece ao sistema industrial do agronegócio, na compra de uma quantidade definida pelo MDA, contribui para a manutenção da subordinação da produção camponesa ao agronegócio. $O$ controle do processo de produção e comercialização é do agronegócio, que vem realizando investimentos em pesquisas e tecnologia para a produção em grande escala de culturas para o agrocombustível (FERNANDES et al., 2011, p. 6).

A inclusão da agricultura camponesa no plano político do PNPB, de certa forma, nos sugere uma contradição, já que o programa tenta unir dois seguimentos historicamente antagônicos e, por vezes, envolvidos em conflitos, vistos na personificação das várias categorias campesinas e do capitalismo financeiro. A partir dos dados da pesquisa, observamos que o selo social tem sido mais um mecanismo da família camponesa ingressar no mercado da oleaginosa, do que de fato cumprir a função social do projeto.

O reflexo das políticas do PNPB na Amazônia tem se dado por meio do cultivo do dendê, que se destaca como uma das oleaginosas propensas à produção dos agrocombustíveis. Com o slogan do desenvolvimento sustentável, o cultivo da palma projeta-se, nessas duas primeiras décadas do século $\mathrm{XXI}$, como um novo componente desenvolvimentista para a região, para o qual o nordeste paraense, na 
concepção do Estado, apresentaria as condições biogeográficas favoráveis para esse empreendimento.

Devido ao seu contexto histórico, o nordeste do Pará tenderia a ser uma região geograficamente ideal para o cultivo da oleaginosa. Nos planos políticos do governo paraense e federal, o cultivo do dendê seria um gerador de trabalho e renda, além de recuperar áreas desmatadas nessa parte da Amazônia. Daí o agronegócio do dendê ser relançado no século XXI com o slogan do desenvolvimento sustentável, na expectativa de retirada dessa região paraense da suposta estagnação econômica e degradação ambiental.

A expansão de plantios da palma entra novamente na pauta das políticas de desenvolvimento da Amazônia, tanto do governo do estado do Pará como também na esfera federal, por meio do PNPB e do Programa de Produção Sustentável da Palma de Óleo do Brasil (PSPOB ${ }^{9}$ ), lançados em 2005 e 2010, respectivamente.

O governo do Estado do Pará também tem estimulado a expansão do agronegócio do dendê por meio da agenda do Plano Estratégico de Desenvolvimento Sustentável do Estado do Pará - PARÁ 2030, lançado em 2016. A agenda propõe agregar valores a partir de supostos ativos ambientais, desencadeando processos produtivos que estimulem a geração de riqueza e renda a partir de projetos de inovação e sustentáveis, que tenham o propósito de integrar o estado. Para isso, foi necessário criar mecanismos para a exploração das riquezas naturais como: minerais, solos, florestas e biodiversidade. Esse dinamismo econômico estaria pautado em práticas sustentáveis (PARÁ 2030).

Destacamos que as políticas públicas direcionadas ao desenvolvimento e à modernização do Estado do Pará estão pautadas na exploração e na valorização dos recursos naturais, que tomam o protagonismo nos centros de decisão e acordos econômicos. A partir desse processo, flexibiliza-se as leis ambientais para que haja conformidade com os projetos de desenvolvimento.

O Estado, nesse processo, adota para si o papel de gerente do espaço geográfico, arquitetando estruturas e incentivos que engendram um reordenamento territorial e ambiental que dê conformidade e garantias econômicas para os grandes

9 Entre os instrumentos indutores do PSPOB no Brasil estão: o zoneamento agroecológico, estipulando uma área de produção máxima autorizada de $13,6 \%$ da área apta ou 3,7\% da área total do território brasileiro; linhas de crédito para o aprimoramento dos instrumentos da cadeia produtiva; investimento em pesquisa e inovação para o melhoramento genético de mudas e sementes de palma; ampliação da oferta de assistência técnica; e criação da câmara setorial da palma de óleo (INCRA, 2017). 
empreendimentos capitalistas. O Zoneamento Agroecológico da Palma de Óleo (ZAE), realizado sob encomenda do Governo Federal, dá parecer favorável para a expansão da oleaginosa no nordeste paraense, ressaltando os aspectos econômicos, sociais e ambientais desencadeados a partir do cultivo do dendê.

\begin{abstract}
A expansão da área cultivada com a palma de óleo (dendezeiro) nas áreas já desmatadas da Amazônia é reconhecida como uma excelente alternativa para a produção de óleo para fins alimentares e energéticos, constituindo suporte tanto para o projeto governamental de ampliação e diversificação da matriz energética brasileira, quanto para a criação de empregos e o aumento da renda da população envolvida nessa atividade. Por outro lado, propicia um melhor aproveitamento das áreas desmatadas e, como consequência, diminui a pressão sobre as áreas de florestas nativas (RAMALHO FILHO; MOTA, 2010, p. 19).
\end{abstract}

Essa perspectiva lançada por Ramalho Filho e Mota (2010) apresenta as supostas vantagens que o Estado pretende alcançar com a produção de dendê, a partir de um estudo geofísico do nordeste paraense, destacando a adaptação da palma africana ao solo e ao clima amazônicos, que dentro de uma perspectiva do desenvolvimento sustentável, solucionaria os problemas sociais e ambientais, além de inserir o Brasil no mercado de óleo de palma em nível global.

Entre os anos de 2000 a 2017, a produção do dendê avança no nordeste Paraense no estado do Pará, formando os latifúndios da palma e em muitas situações avançando sobre territórios camponeses e quilombolas impondo-se como uma mancha verde no mapa do estado.

\title{
Mapa 01: Área do dendê no estado do Pará no ano de 2016.
}

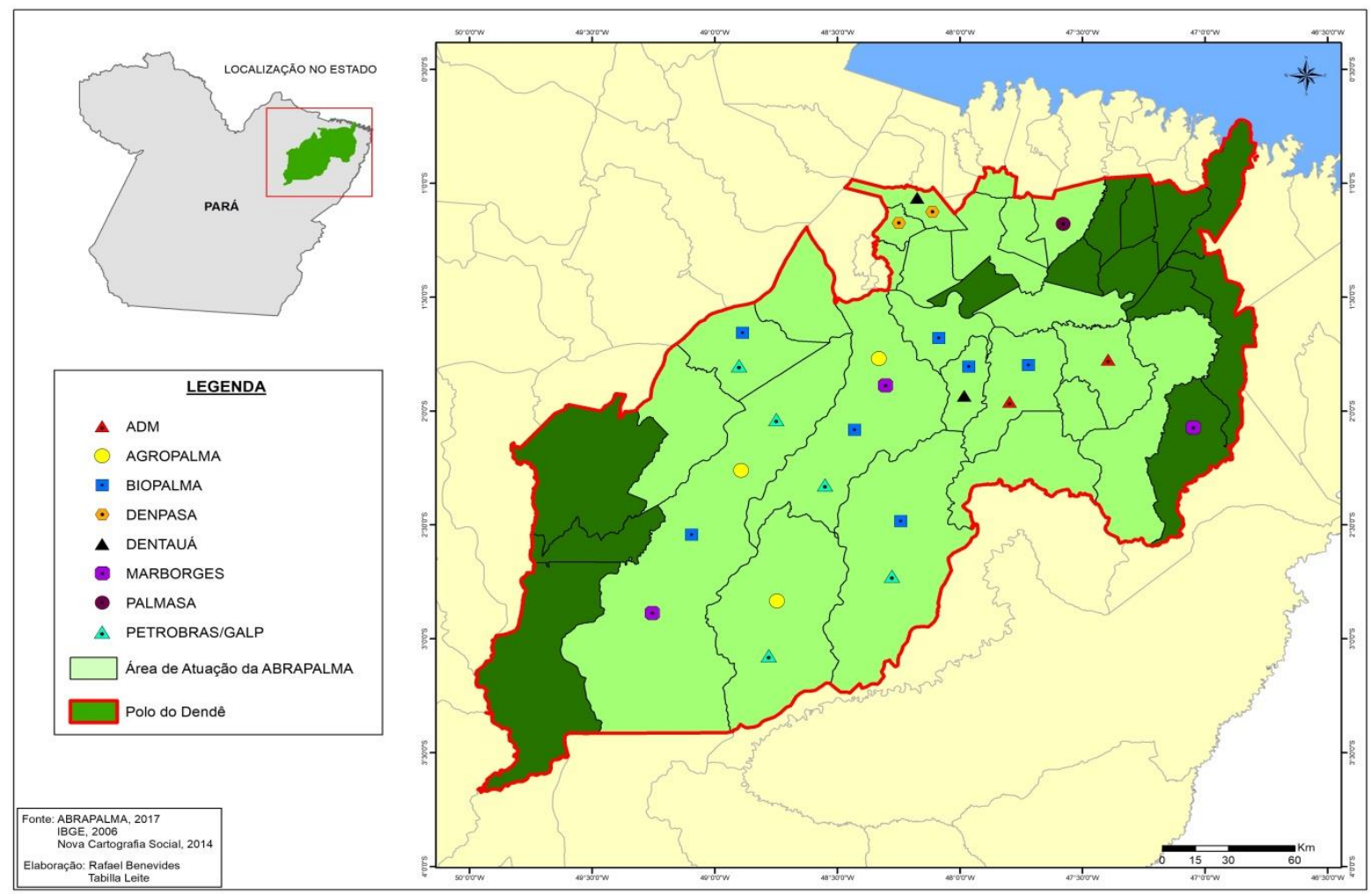


No mapa 01 visualizamos a concentração do Polo do dendê no estado do Pará, abrangendo cerca de 36 municípios. Já a Associação Brasileira de Produtores de Óleo de Palma - Abrapalma está presente em 23 municípios paraense, por meio de oito empresas: ADM do Brasil Ltda; Agropalma; Belém Bioenergia Brasil - BBB; Biopalma; Denpasa; Dentauá; Marborges e Palmasa. A Abrapalma, criada em 2012, tem como objetivo tornar o Brasil líder mundial na produção de óleo de palma. Atualmente, as empresas associadas respondem pela maior parte da produção, industrialização e comercialização dessa oleaginosa no país (ABRAPALMA, 2016).

A tabela 01 demonstra uma estimativa da produção do dendê no estado, por meio das empresas produtoras da oleaginosa entre 2011 a 2018.

\begin{tabular}{c|c|c|c|c|c|c|c|c}
\hline \multicolumn{7}{c}{ Tabela 01: Estimativa da produção de óleo de dendê do Estado do Pará (t) } \\
\hline Empresa & $\mathbf{2 0 1 1}$ & $\mathbf{2 0 1 2}$ & $\mathbf{2 0 1 3}$ & $\mathbf{2 0 1 4}$ & $\mathbf{2 0 1 5}$ & $\mathbf{2 0 1 6}$ & $\mathbf{2 0 1 7}$ & $\mathbf{2 0 1 8}$ \\
\hline ADM & - & - & - & - & 6.721 & 9.663 & 15.202 & 17.159 \\
\hline Agropalma & 151.100 & 165.000 & 165.000 & $\begin{array}{c}165.000 \\
0\end{array}$ & 165.000 & 165.000 & 165.000 & 165.000 \\
\hline Biopalma & - & 16.000 & 62.032 & 118.562 & 215.939 & 323.564 & 383.973 & 454.696 \\
\hline Denpasa & 6.380 & 6.380 & 6.380 & 6.000 & 34.000 & 35.000 & 23.000 & 23.000 \\
\hline Dentauá & 9.634 & 12.600 & 12.600 & 12.600 & 12.600 & 12.600 & 12.600 & 12.600 \\
\hline Marborges & 14.200 & 12.295 & 12.766 & 15.649 & 15.110 & 15.535 & 16.360 & 16.450 \\
\hline Palmasa & 12.000 & 12.500 & 13.500 & 13.500 & 13.500 & 13.500 & 13.500 & 13.500 \\
\hline BBB & - & - & 3.840 & 17.740 & 47.064 & 72.730 & 102.100 & 128.224 \\
\hline Mejer & - & - & 30.000 & 35.000 & 42.500 & 48.000 & 62.900 & 65.000 \\
\hline Bahia & - & - & 34.525 & 34.525 & 34.525 & 34.525 & 34.525 & 34.525 \\
\hline Total & 193.314 & 225.775 & 340.643 & 418.576 & 586.959 & 730.117 & 829.160 & 930.154 \\
\hline
\end{tabular}

Fonte: YOKOYAMA (2015, apud HOMMA, 2016)

A tabela 01 apresenta as estimativas das empresas produtoras do dendê até 2018, com um aumento considerável da produção de óleo de palma no estado do Pará. Entre as maiores produções destacam-se as metas das empresas Biopalma, Agropalma e a BBB, que possuem áreas de produção próprias e em consórcio com a agricultura camponesa.

Entre os destinos da produção do óleo de palma produzido no estado do Pará, encontramos países da América Latina, Europa e os Estados Unidos, sendo a Colômbia o principal país dos acordos comerciais. Com esse mercado de óleo de palma global, o governo do Estado do Pará tem criado estratégias de aumento da produção da oleaginosa, arquitetando uma rede de infraestrutura e incentivos que deem conformidades aos grandes empreendimentos.

Diante de uma demanda mundial de alimentos, a Agenda PARÁ 2030, do governo do paraense (2011-2018), projeta uma política agrícola estadual, assentada na verticalização do setor agropecuário, baseando-se na premissa da segurança alimentar, na recomposição da cobertura vegetal e na economia de baixo carbono. 
Desse modo, intensifica-se mais uma vez uma fronteira agrícola do país, disponibilizando mecanismos operacionais e estratégicos para a implantação de projetos agropecuários, tais como: condições naturais favoráveis (solo e clima), disponibilidade de terra com preço competitivo, ZEE realizado, CAR em estágio avançado (87,82\% da área cadastrável realizado), programa de regularização ambiental com normatização já elaborada, posição geográfica favorável, e nova rota de exportação: ampliação dos investimentos em logística (PARÁ, 2016).

O Estado do Pará hoje é o maior produtor de dendê do país com $83 \%$ da produção nacional. De acordo com dados fornecidos pela Agenda PARÁ 2030 (2016), o Estado possui 166 mil hectares de dendê, com uma produção de óleo de 350 mil toneladas. Contudo, a partir de dados disponibilizados pelo site do IBGE sobre a lavoura permanente do ano 2016, confirmou-se que a área de cultivo do dendê no Estado girava em torno de 99.212 hectares, distribuída em 36 municípios do nordeste paraense.

Dentro dessa perspectiva lançada pelo estado, projeta-se, no século XXI, a continuada concentração de terra na Amazônia, assegurada pelos incentivos ao desenvolvimento da agroindústria do dendê. Pela observação de um processo denominado green grabbing, Backhouse (2013, p. 10), ao pensar criticamente a desapropriação sustentável na Amazônia, chama a atenção para o "fato de que o uso e o acesso à terra tem sido controlados pelo setor agroindustrial de óleo de palma, o qual, em interesse próprio, reorganiza e legitima a atividade como 'sustentável'”. Assim, a suposta recuperação de áreas degradadas torna-se uma desculpa do estado para legitimar a reconfiguração fundiária, novamente concentrada nas mãos do capital.

O conceito de degradação ambiental nesse contexto parte de uma perspectiva ideológica do geografismo e do biologismo que desculpam a ação e a intervenção do capital na Amazônia pela lógica desenvolvimentista do estado e do capital. Almeida (2008, p. 18) alerta para a definição de degradação, dizendo que esta emerge "objetivamente como diminuição ou como perda: perda de intensidade e perda de qualidade com seus efeitos referindo-se a fatores de destruição da cobertura vegetal, de 'esgotamento do solo' e de alterações nos cursos d'água." Desse modo, entende-se esse processo de desmatamento dentro apenas de uma circunstância ambiental, não levando em consideração os aspectos sociais que culminam na fragilização da natureza. 
Para Almeida (2008, p. 20), “ao discutir a noção de 'degradação' está em jogo uma ideia da 'natureza' abrangente e bem circunstanciada, que não pode mais ser entendida simplesmente enquanto 'quadro natural' ou 'meio físico'”. Nesse sentido, ao invés do estado realizar um processo de reforma agrária, via a desapropriação, e construir uma equidade social de acesso à terra, ele tem feito o oposto, o que dentro da perspectiva do green grabbing (BACKHOUSE, 2013) e/ou do processo de estrangeirização da terra (FERNANDES, 2011; 2017), revitaliza o latifúndio, no nordeste paraense, com a expansão da produção da palma de óleo.

As políticas públicas direcionadas à expansão do dendê na Amazônia partem de uma visão eldoradista, a qual concebe os recursos naturais como uma expressão regional (ativos ambientais) diante da ilusão desenvolvimentista do atual estágio do capitalismo financeiro (SVAMPA, 2012). Com o propósito de atingir o superávit da balança comercial, o Estado estrutura uma produção pautada no comercio exterior, tornando o dendê um importante componente agrícola mundial, recebendo incentivos para sua expansão territorial.

O PNPB, PSOB e o PARÁ 2030 são políticas de incentivos do Estado que confluem para o que Svampa (2012) denomina de consenso de commodities, que seria o fruto das políticas dos governos de esquerda/progressista e conservadora na América Latina. No caso do Brasil, essas políticas são oriundas dos governos petistas Lula-Dilma, e no Pará, do PSDB de Simão Jatene. Para a autora, o consenso de commodities seria o aprofundamento da dinâmica da acumulação por espoliação, delineada por Harvey (2014). Esta por sua vez, contempla desde o setor extrativista (mineral, hidrelétricos) até o agronegócio para a produção de agrocombustíveis, que apresenta tendência para a consolidação de um modelo de monocultura, com base na desestruturação e na reorientação de territórios, na destruição da biodiversidade e no aprofundamento do processo de aprisionamento da terra.

Nessa mesma linha de raciocínio, Zibechi (2014) expõe o neocolonialismo que se instala na América Latina, por meio de uma nova perspectiva exploratória dos recursos naturais, atualizando o sistema colonial pautado na reprimarização da matriz produtiva. O autor chama a atenção para a expansão e a territorialização da mineração e de monoculturas sobre territórios indígenas, quilombolas e camponeses, o que, por sua vez, gera um processo de desterritorialização, colocando em questão a reprodução do bem viver em comunidades e a vulnerabilidade do território diante do capital. 
O neocolonialismo tende a gerar uma disputa pelo território que é reproduzido a partir de relações assimétricas de poder entre as empresas transnacionais, o Estado e a população (ZIBECHI, 2014). Tais relações de poder tendem a gerar uma economia de enclave. Para Zibechi (2014), os enclaves representavam as principais formas de ocupação do período colonial, caracterizando-se por não ter relações com o entorno, reproduzindo uma economia vertical que não se articulava com a população. Nesse caso, o capital extrai a renda da terra, exporta a produção, mas não interage com o meio circundante, empobrecendo o local, o tecido social e exilando a população. Essa perspectiva seria um dos limites do agronegócio do dendê, ao passo que sua territorialização no campo paraense tem provocado uma vulnerabilidade dos territórios campesinos, gerando uma disputa territorial constante.

A conformação dessas economias de enclave articula-se a partir das agroestratégias que o Estado e o capital nacional e estrangeiro assumem para construção dos grandes empreendimentos na Amazônia, criando mecanismos de apropriação e dominação de terra-territórios voltados à reprodução capitalista do capital. Para Almeida e Marin (2010) essas agroestratégias são geradas a partir das táticas empresariais que, de diferentes maneiras tentam territorializar-se no campo, pressionando os territórios das populações tradicionais e burlando os direitos territoriais.

O agronegócio do dendê expande-se no nordeste paraense dentro dessa perspectiva enunciada pelos autores, ocasionando o aprisionamento da terra nas mãos do capital nacional e estrangeiro que entram no mercado mundial de óleo de palma. Com isso, tem-se a compressão dos territórios camponeses, indígenas e quilombolas que, cercados pelos canteiros da oleaginosa, tentam converter a pressão territorial em estratégias para manter-se ligado a terra e ao território e assim assegurar a sua reprodução social.

A conformação territorial dos latifúndios do dendê tem sido o reflexo do processo de acumulação por espoliação reproduzida a partir do capitalismo financeiro. As políticas direcionadas para a oleaginosa fomentaram uma capitalização/privatização da terra, gerando expropriação e subordinação camponesa e aumento a concentração da terra em latifúndios verdes.

Diante da biodiversidade florística da Amazônia, a produção em monocultura inseridas nesse ecossistema já deu sinais de fracasso, é o caso emblemático da racionalização da seringueira (hevea brasiliensis) no Projeto Fordlândia, no Rio 
Tapajós ${ }^{10}$, e da pimenta do reino no município de Tome-açu. $O$ dendê também já teve problemas relacionados ao seu monocultivo, como é o caso do amarelamento fatal, que dizimou vários canteiros da palma. Atualmente, o cultivo da oleaginosa tem se dado sobre fortes doses de agrotóxico, com o intuito de manter os canteiros do dendê verdes e produtivos.

A sustentabilidade no cultivo da palma ocorre apenas no plano político da produção do biodiesel. Na realidade, a suposta recuperação de áreas degradadas, dar-se, automaticamente, em um processo degradante, colocando em prática a insustentabilidade do projeto geopolítico do biodiesel "limpo".

Para McMichael (2016), o aumento da produtividade de alimentos, de combustíveis verdes e até da compensação de carbono influenciam em direção a um processo de apropriação de terras pelo capital, implicando na remoção em larga escala das populações rurais de terras ancestrais. Sobre o óleo de palma, o autor se apoia no seguinte relato da ONU:

\begin{abstract}
A experiência com plantações de palma para a extração de óleo na [...] Indonésia demonstra de modo conclusivo que a propriedade e outros direitos de povos nativos são desprezados, seu direito a ser consultado não é respeitado, alguns são desalojados e deixados sem outra alternativa que não a de se tornar de facto trabalhadores forçados colhendo os frutos da palma para as empresas que administram as plantações (apud SMOLKER et al., 2008, p.30 apud MCMICHAEL, 2016, p. 166).
\end{abstract}

O processo de territorialização da palma no espaço agrário mundial vem acontecendo por uma expectativa de mercado, isso tende a gerar um conflito de interesse entre uma experiência de vida e de trabalho local em relação a homogeneização imposta pelos processos de produção global.

Em outras palavras, commodities a granel, como trigo, milho, arroz, soja, açúcar e óleo de palma, são a extensão lógica de um futuro agroindustrial, ou regime de biomassa, movido por uma demanda altamente subsidiada. Essa cláusula de salvaguarda temporária para o capital (que protela 0 esgotamento do ecossistema) requer a espoliação e/ou incorporação de pequenos produtores a cadeia de valor, em que todos os cultivos sejam fungíveis e, em última instância, subordinados a um cálculo financeiro, em vez de social. Essa visão pressagia um regime intercambiável de alimento/ ração animal/ combustível baseado em ondas de apropriação de terras e no surgimento de novas rotas sul-norte, leste-norte, leste-sul e sul-sul de alimentos, combustível e biomassa (MCMICHAEL, 2016, p. 167).

\footnotetext{
10 "Idealizada por Henry Ford, na década de 1920, a plantation destinada ao cultivo da borracha, no Vale do Tapajós, onde se localiza atualmente um empreendimento fracassado, gerando passivos ambientais e sociais, devido a sua não adequação as condições edáficas locais, proporcionando o aparecimento de pragas [...], e também pelas rígidas condições de trabalho impostas pelos empreendedores, que não se atentaram para as peculiaridades de moradia e alimentação locais. Em 1945, Ford abandonou a empreitada repassando as instalações ao Governo Brasileiro [...]" (BINSZTOK; CARNEIRO, 2015, p. 97)
} 
A produção em commodities tende a gerar um reordenamento do território para a implantação e expansão da agroindústria. No caso do dendê, empresas nacionais (estatais e privadas) e estrangeiras têm recebido fortes incentivos por meios dos programas já mencionados anteriormente. Nesse interim, a territorialização da oleaginosa no nordeste do Pará está pautado na articulação entre o Estado e o capital, ao passo que o Estado é o principal incentivador do empreendimento com financiamento do setor público. Em contrapartida, as empresas transnacionais expandem sua área de produção, perpetuando os latifúndios e a ampliação de capital a partir da renda da terra.

Em meio a esse processo, as comunidades camponesas têm visto seus territórios serem cercados pela palma e, de certa forma, aprisionados por uma agricultura estranha ao seu modo de vida e produção. Sendo assim, o tema campesinato continua na agenda do dia, seja para traçar sua tragédia social, via o processo de descampesinização (NAHUM; BASTOS, 2014), seja para desvendar os elementos que permeiam a sua recriação no bojo do desenvolvimento desigual e combinado do capital (SOUSA, 2014; MACEDO; SOUSA, 2016).

Apesar do boom do dendê ter se dado a partir das políticas de matriz energéticas, para a produção de combustível menos poluente e de fonte renovável, a oleaginosa tem se destacado como um componente em potencial para a produção de alimento, tornando-se matéria-prima importante nas commodities alimentícias.

Dentre as principais empresas processadoras do dendê para fins alimentícios, destacam-se a Agropalma ${ }^{11}$ e a $\mathrm{ADM}^{12}$. Essas empresas fazem parte do circuito do regime alimentar ${ }^{13}$ que tem influenciado no processo de mercantilização da agricultura e dos recursos naturais em nível global.

A hegemonia de mercado define o terceiro regime alimentar e seu papel em um amplo projeto neoliberal dedicado a assegurar rotas transnacionais de capital e commodities (incluindo alimentos) - transformando pequenos agricultores em uma força de trabalho global informal em prol do capital. A

\footnotetext{
${ }_{11}$ De acordo com o site da Abrapalma, a Agropalma é uma empresa voltada para a comercialização e "produção de mudas, plantio e cultivo de palma, extração de óleos brutos (palma e palmiste), refino e produção de gorduras vegetais."

12 De acordo com o exposto no site da Abrapalma, a ADM é uma empresa com especialidade no setor Trading e processamento de commodities agrícolas.

${ }^{13}$ McMichael (2016) chama a atenção para três fases do regime alimentar mundial. O primeiro estaria centrado na hegemonia da Grã-Bretanha (1879-1930), no qual dentro de um sistema colonial, importava produtos tropicais básicos para abastecer a classe industrial emergente. $O$ segundo momento vai estar centrado nas políticas desenvolvimentistas, direcionadas pelos Estados Unidos (1950-1970), dentro de uma perspectiva de internalizar um modelo da agroindustrialização estadunidense, adotando a tecnologia da revolução verde como meta produtiva. A terceira fase do regime alimentar (1980-2000) está atrelado ao processo de globalização econômica, regido por corporações integradas a cadeias produtivas diferenciadas, produzindo uma diversificação produtiva entre alimentos de qualidade e padronizados (MCMICHAEL, 2016).
} 
incidência cíclica e os vestígios transicionais dos regimes alimentares sinalizam uma verdade subjacente, a saber, que o sistema estatal está profundamente arraigado em relações agroalimentares. Hoje, no século $X X I$, a civilização humana não tem nenhum outro fundamento mais importante do que seus ecossistemas e fonte de abastecimento alimentar, e a ordem política contemporânea ignora tal fato por sua (e nossa) conta e risco (MCMICHAEL, 2016, p. 15-16).

A expansão do dendê nesse início de século XXI pode ser compreendida por essa lógica dos regimes alimentares, como o reflexo de uma ordem política global sobre parte do espaço Amazônico. O ideário ufanista que vigora sobre o desenvolvimento do nordeste paraense pode ser a desculpa ideal para a estrangeirização da terra na região. A estruturação do regime alimentar "assinala o processo de mercantilização do alimento e a elaboração de relações comerciais fundamentadas na conversão progressiva da agricultura a uma indústria mundial" (MCMICHAEL, 2016, p. 43).

A industrialização da agricultura de alimento, de ração animal e de combustível tem sido uma tendência na ordem global capitalista que influencia os territórios com tradições produtivas em nível local. A territorialização do dendê pelo espaço agrário paraense reflete-se como uma agricultura estranha ao modo de vida do camponês amazônico, acostumado a um sistema de roça itinerante, tendo na produção de mandioca e na policultura os meios de sobrevivência da família.

Os municípios do nordeste do Pará têm em seu histórico uma relação produtiva muito forte com o cultivo da mandioca. Organizado em sistema de roça consorciada e itinerante, o tubérculo orquestra nos territórios campesinos uma produção agrícola voltada à confecção da farinha, que pode ser comercializada ou apenas usada para o consumo doméstico.

Com a territorialização do dendê pelo agrário paraense, a produção da mandioca teve uma diminuição das áreas produtivas, ocasionando, em 2012, elevação do preço no mercado regional. No gráfico a seguir, fazemos uma comparação entre as áreas de produção da mandioca e do dendê nos anos de 2006 e 2016. 


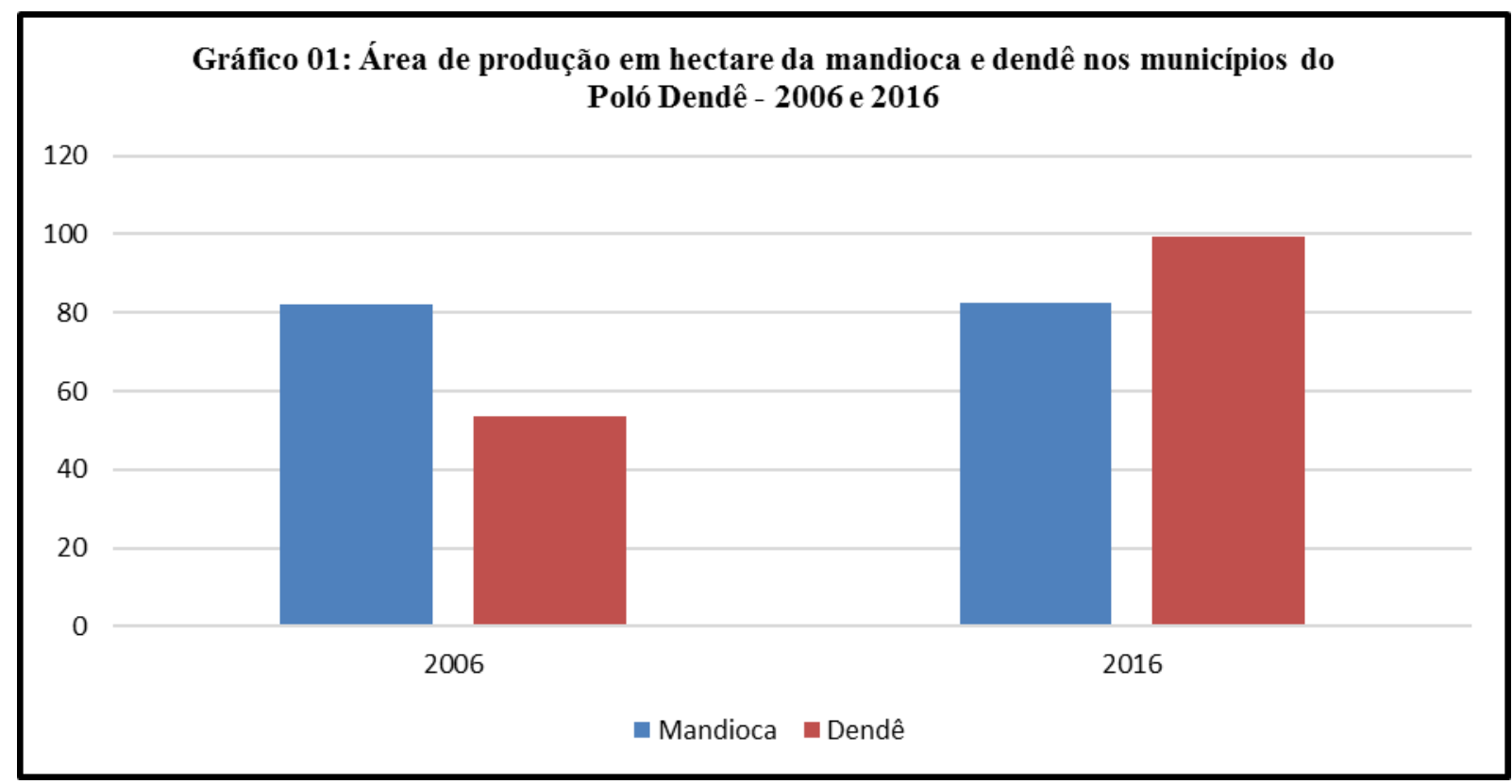

Elaboração: Sousa, Macedo.

Fonte: IBGE (2017)

Observamos no gráfico 01 a superação da área de produção da oleaginosa sobre a produção da mandioca nos municípios que compreende o polo do dendê paraense. Contudo, evidenciamos que a porcentagem da área de produção da mandioca continuou estável em comparação ao período tabulado, havendo apenas o aumento da área de cultivo da palma.

Compreende-se assim, enquanto ocorre a expansão da oleaginosa pelo agrário do paraense, que as propriedades camponesas têm mantido sua base produtiva, para a qual a agricultura de roças ainda se mantém presente no nordeste do Pará.

A partir da expansão do dendê, inicia-se uma disputa pelo território alicerçado em padrões de uso da terra totalmente opostos. De um lado, o agronegócio da palma de óleo que tem concentrado a terra, recrutando mão de obra camponesa e engendrando, nas propriedades familiares de camponeses, a produção da palma com a perspectiva de aumentar a renda familiar. Do outro, encontramos famílias camponesas que tem grafado na terra suas estratégias para a manutenção da unidade doméstica, ressignificando suas territorialidades a partir da apropriação das sutilezas que a agricultura capitalista do dendê tende a oferecer, ou mesmo mantendo a autonomia produtiva familiar camponesa.

Nas representações cartográficas a seguir, observamos a disputa territorial entre o dendê e a mandioca no nordeste paraense. 


\section{Mapa 02: Área de cultivo do dendê em 2006}

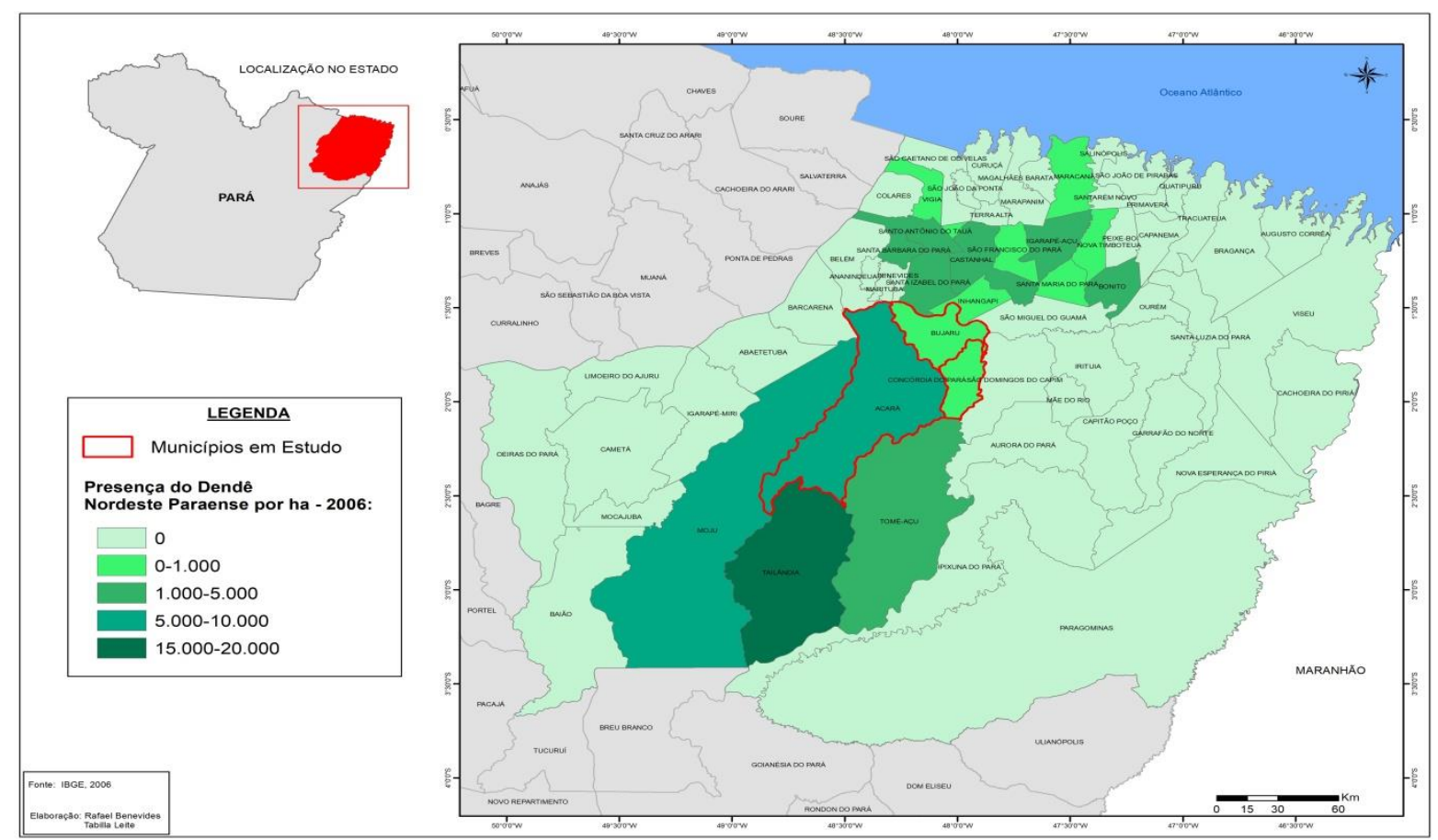

\section{Mapa 03: Área de cultivo do dendê em 2016}

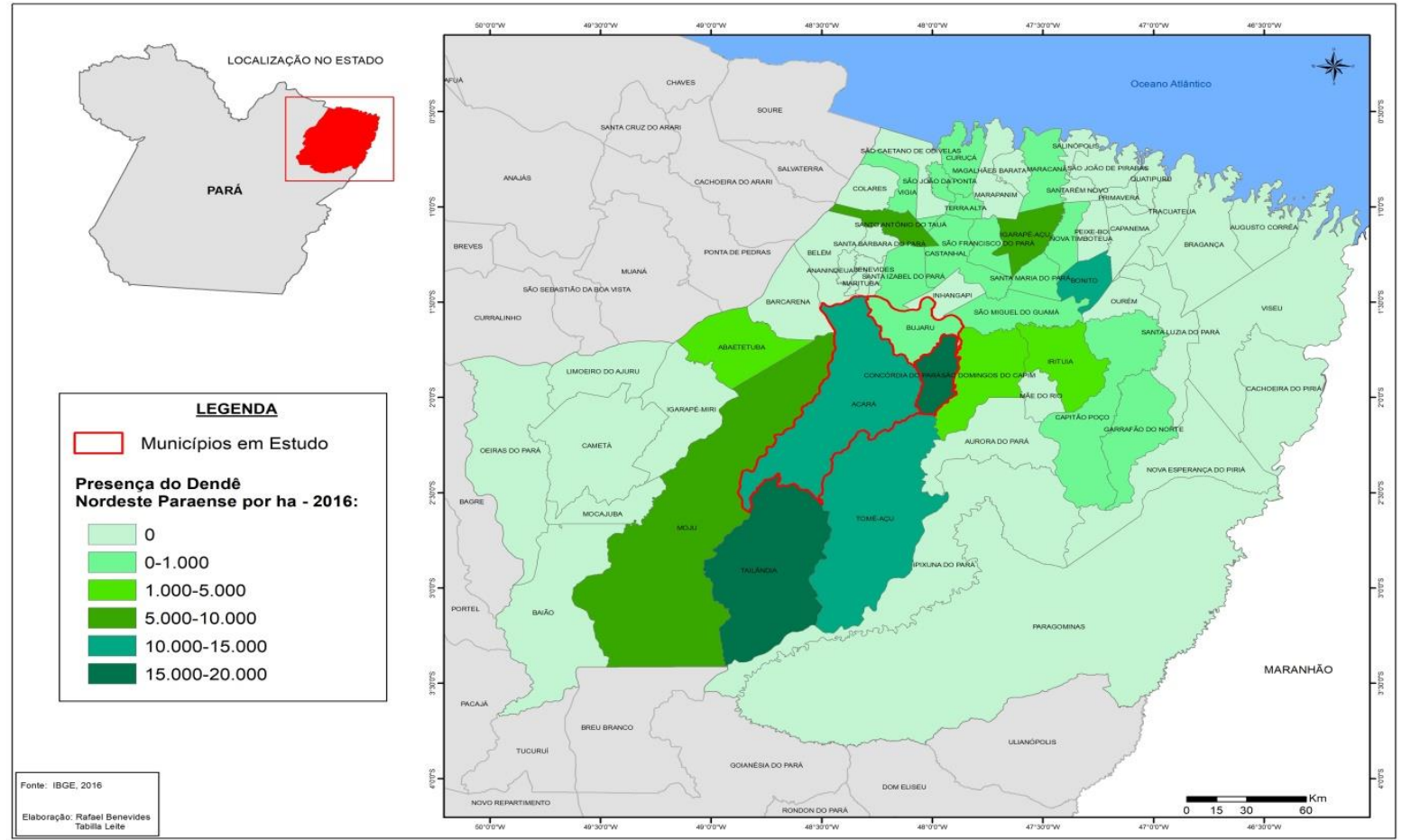

No mapa 02, observamos que em 2006 o agronegócio do dendê estava territorializado em 19 municípios do nordeste paraense. O que demonstra já haver uma maior concentração da oleaginosa nos municípios que compõem a região Guajarina, como Tailândia, Acará e Moju, com maior produção da oleaginosa. 
Já no mapa 03, percebemos que em 2016 as maiores áreas de produção do dendê ainda continuam concentradas na região Guajarina, havendo um aumento significativo nos municípios de Bonito, Concórdia do Pará e Tomé-açu, sendo os dois últimos inseridos nos polos de produção da empresa Biopalma, uma das maiores produtoras da oleaginosa no estado. Tailândia (maior produtor do Pará) e Acará seguem também com uma grande extensão de terra com a palma de dendê plantado.

A comparação entre os dois mapas nos leva a visualizar o aumento da área de produção da palma do dendê nessa parte da Amazônia, bem como a territorialização por outros municípios. $O$ aumento da área de cultivo da oleaginosa faz crer que seja essa a explicação pelo aumento dos preços da farinha de mandioca em 2012, havendo uma pressão da palma africana sobre o tubérculo amazônico.

Notadamente, até 2016, o cultivo do dendê concentrou sua maior área de produção pela região Guajarina, adentrando pelas proximidades das bacias hidrográficas dos rios Acará e Guamá, ocasionando no aprisionamento da terra e na concentração fundiária com o latifúndio da palma. É nessa parte do nordeste paraense também que estão as empresas processadoras e extração do óleo de dendê, a exemplo da Agropalma e da Biopalma.

Nos mapas a seguir, observaremos as áreas de produção da mandioca, nos mesmos anos de análise realizada com a palma de óleo. 


\section{Mapa 04: Área de cultivo da mandioca em 2006}

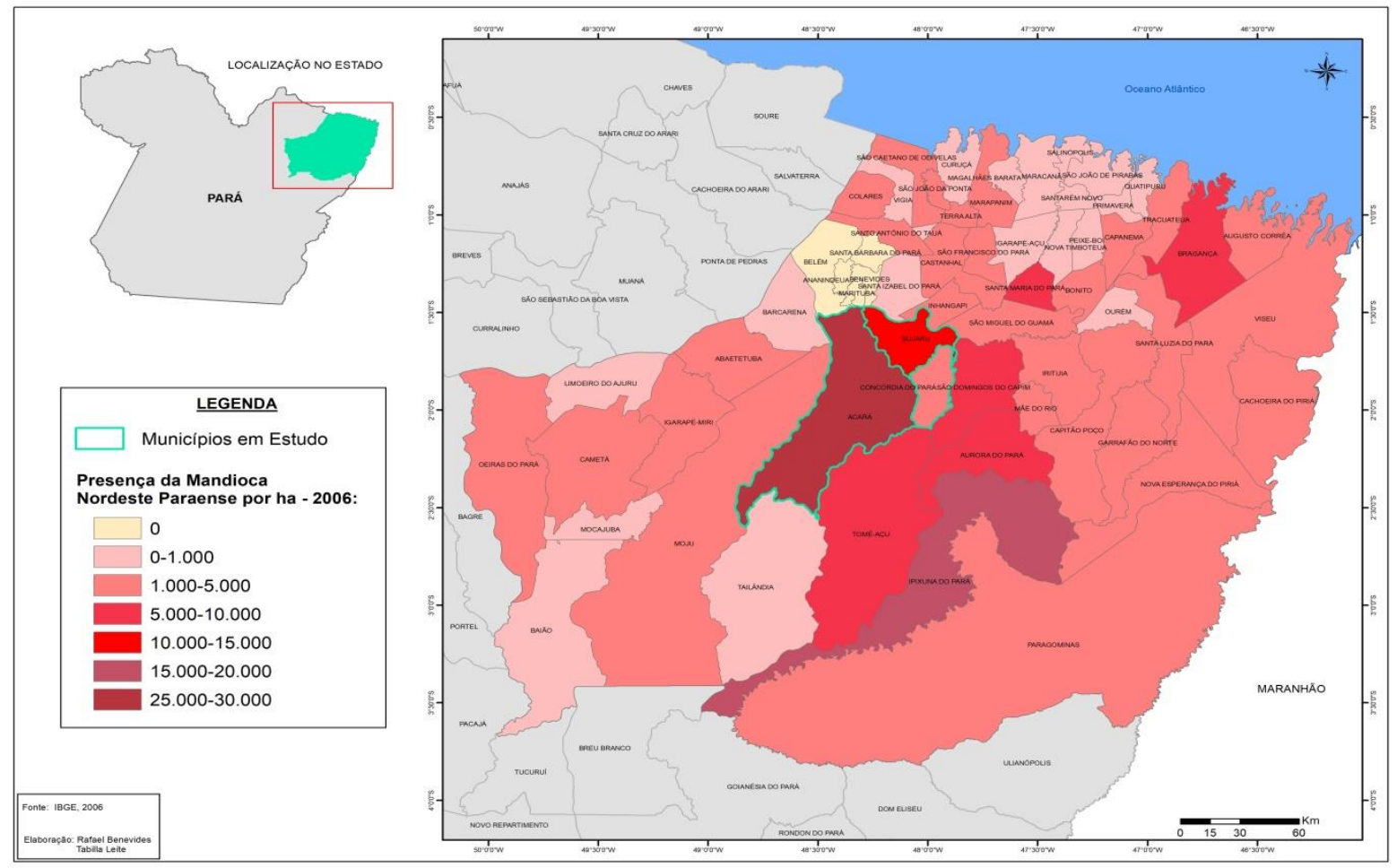

\section{Mapa 05: Área de cultivo da mandioca em 2016}

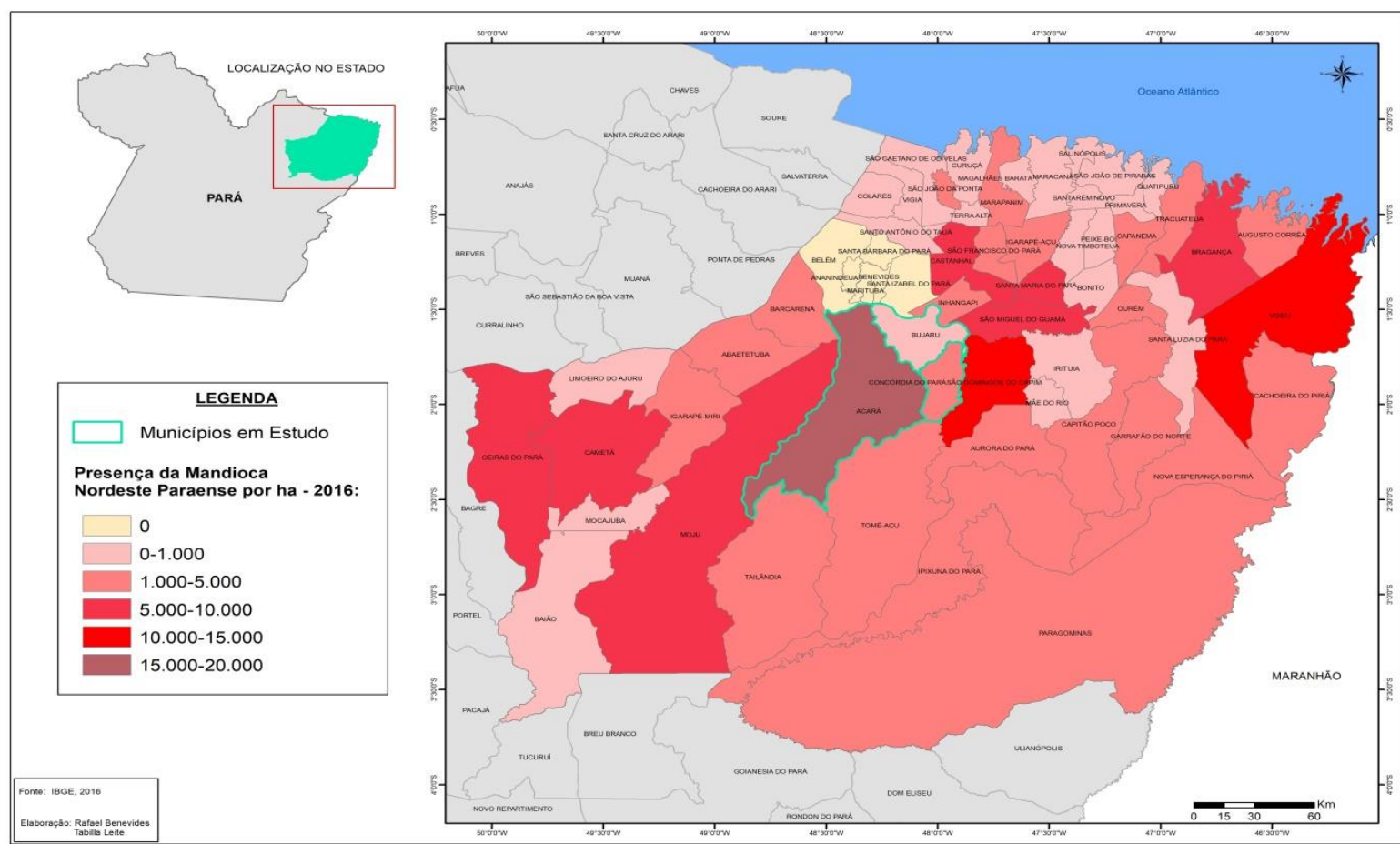

Os mapas 04 e 05 demonstram a espacialização do cultivo da mandioca pelo nordeste paraense, sinalizando uma forte presença camponesa nessa região amazônica. Observamos nos mapas que nos municípios em que houve o aumento da área do dendê também teve o aumento da área de produção da mandioca, ou 
mesmo está se manteve estável. Contudo, chama-se a atenção para o município de Bujaru, onde não houve um aumento da área de produção do dendê (ver mapas 02 e 03), mas houve a diminuição da área de cultivo da mandioca, levando a consideração da existência de outras agriculturas ou fontes de renda na unidade familiar camponesa.

Diferente do dendê, a produção da mandioca está territorializada por quase todo nordeste paraense, como podemos observar nos mapas 04 e 05. Destaca-se o município de Acará que, mesmo com a diminuição da área de cultivo, manteve-se como o maior produtor do tubérculo, e, em 2016, tornou-se um dos maiores produtores de dendê no estado.

$\mathrm{Na}$ comparação entre os dois mapas referentes à produção da mandioca, observamos que as tonalidades mais escuras aumentaram em 2016, significando que ocorreu um aumento de áreas de cultivo de roças de mandioca, dado significativo de que o dendê não tem homogeneizado suas áreas de plantio por toda a região.

A intensidade da produção da mandioca nos sugere que existe um campesinato forte no nordeste paraense, e mesmo nos municípios em que o dendê tem se territorializado, o sistema de roça ainda se faz importante na geração de renda nesse espaço agrário. Além da mandioca, o cultivo da pimenta-do-reino, legumes e frutas e a extração do açaí também podem ser considerados componentes importantes na produção agroextrativista camponesa local, inserindo a produção familiar nas relações comerciais amazônicas.

A espacialização do cultivo da mandioca pelo nordeste paraense, enquanto uma produção da agricultura camponesa, contraria a tese da descampesinização (NAHUM; BASTO, 2014) e da subordinação dos territórios camponeses ao dendê (OLIVEIRA NETO, 2017), sinalizando que o trabalho assalariado e a integração ao cultivo da oleaginosa condiz como uma estratégia camponesa de reforçar a unidade doméstica, não necessariamente uma transição da agricultura de roça para a da palma do dendê.

\section{Considerações Finais}

A expansão do cultivo do dendê no nordeste paraense, e a sua tentativa de territorialização do capital, promoveu contraditoriamente nos territórios campesinos o soerguimento das estratégias historicamente construídas para a garantia da sua 
reprodução social. Em meio as tensões provocadas nesse campo de disputa, a terra encolheu, os braços se desdobraram entre a roça e os campos do dendê, a família nuclear tornou-se extensa, ensaiando novas estratégias de ação que se constituíram nos pilares do processo de campesinização.

Nesse mesmo compasso, a luta pelo território tornou-se o elemento chave, uma vez que desdobraram-se ações no sentido da garantia do direito de poder usufruir do bem comum ali existente. Da mesma forma, visualizou-se o acionamento da cultura local e seus elementos identitários na construção da luta. Em tempos de dendê foi necessário redimensionar a produção camponesa e de certa forma, a dinâmica familiar e comunitária em decorrência da saída para o trabalho nos campos com a palma de óleo. Nesse contexto, homens assumiram dupla jornada de trabalho ou transformaram a roça em atividade de fins de semana. Já a mulher, assumiu o controle de atividades que até recentemente era atividade de homem, como por exemplo, o preparo da farinha de mandioca.

Impõe-se o tempo do relógio e do controle de ponto aos camponeses. Porém, verifica-se adaptabilidades desses camponeses na recondução do seu tempo, garantindo assim, a coexistência do modo de vida camponês em meio a tentativa de ruptura da autonomia e das redes de sociabilidade e vizinhança imposta pelo ritmo do trabalho assalariado.

Neste sentido, podemos inferir que a expansão da produção do dendê nessa região da Amazônia, não tem conseguido promover a proletarização camponesa. A pesquisa nos mostrou que o assalariamento temporário desse campesinato, tem contribuído decisivamente para a garantia da sua reprodução.

\section{REFERÊNCIAS}

ABRAPALMA. Abrapalma. Disponível em: http://www.abrapalma.org/pt/ (Acessado em 14 de abril de 2018)

ALMEIDA, A. W. B. \& MARIN, R. A. Campanhas de desterritorialização na Amazônia: o agronegócio e a reestruturação do mercado de terras. In.: BOLLE, W. et Al. (ORGs.). Amazônia: região universal e teatro do mundo. São Paulo: Globo, 2010.

Antropologia dos archivos da Amazônia. Rio de Janeiro: Casa 8 / Fundação Universidade do Amazonas, 2008.

BACKHOUSE, M. A despropriação sustentável da Amazônia. 0 caso de investimentos em dendê no Pará, Fair Fuels? Working Paper 6, Berlin, 2013.

BINSZTOK, J.\& CARNEIRO, M. R. D. Integração nacional, desenvolvimento capitalista e projetos modernizantes na Amazônia: retrospectiva e perspectiva de despojo da mineração Rio do Norte - Pa. Revista NERA (UNESP), v. 28, 2015, p. 92-105. 
BOARI, A. J. Estudos realizados sobre o amarelecimento fatal do dendezeiro (Elais Guineensis Jacq). Belém, PA: Embrapa Amazônia Oriental, 2008.

CARVALHO, A. C. A \& NAHUM, J. S. Período do Dendê na Amazônia Paraense. In.: NAHUM, J. S. (ORG.). Dendeicultura e dinâmicas territoriais do espaço agrário na Amazônia paraense. Belém: GAPTA/UFPA, 2014.

DROUVOT, C. M. \& DROUVOT, H. O Programa de Produção Sustentável do Dendê na Amazônia: a mobilização dos grupos de interesse no reflorestamento das áreas degradadas. 6ํㅡㄹ Congresso do Instituto Franco-Brasileiro de Administração de Empresas. Inovação, Cooperação Internacional e Desenvolvimento Regional. IFBAE, Franca, 2011.

FABRINI, J. E. O campesinato frente à expansão do agronegócio e do agrocombustível. In.: SAQUET, M. A. \& SANTOS, R. A. (ORGs.) Geografia Agrária, território e desenvolvimento. São Paulo: Expressão Popular, 2010.

FERNANDES, B. M. Transformações no Brasil agrário nas fases neoliberais e pós-liberais: construindo uma política agrária para um desenvolvimento sustentável. In.: SUERTEGARAY, D. M. A. (ORGs.). Geografia e conjuntura brasileira. $1^{\underline{a}}$ ed. Rio de Janeiro: Consequência Editora, 2017, p. 75-111.

et al. Políticas de agrocombustíveis no Brasil: paradigmas e disputa territorial. Espaço Aberto, v. 1, p. 14-37, 2011.

GONÇALVES, C. W. P. Amazônia, Amazônias. 3ª ed. São Paulo: Contexto, 2010.

A ecologia política na América Latina: reapropriação social da natureza e reinvenção dos territórios. Intertheses. Vol. 09 - № 1. Jan/jun 2012.

GUDYNAS, E. Diez tesis urgentes sobre el nuevo extractivismo. Contextos y demandas bajo el progresismo sudamericano actual. In: VVAA. Extractivismo, política y sociedade. QuitoMontevideo: CAAP e CLAES, 2009, p. 187-225.

HARVEY, D. O novo imperialismo. Tradução Adail Sobral, Maria Stela Gonçalves $-8^{\mathbf{a}}$ ed. - São Paulo: Edições Loyola, 2014.

HOMMA, A. O desenvolvimento da agroindústria no Estado do Pará. Saber, ciências exatas e tecnologia. Belém, v. 3, Edição Especial, jan/dez, 2001, p. 49-76.

Cronologia do cultivo do dendezeiro na Amazônia. Belém-PA: Embraa Amazônia Oriental, 2016.

IBGE. Cidades. Fonte: https://cidades.ibge.gov.br/ (Acessado em 07 de JANEIRO DE 2018) INCRA. Governo Federal lança Programa de Produção Sustentável de Óleo de Palma. Disponível em: http://www.incra.gov.br/governo-federal-lanca-programa-de-producaosustentavel-de-oleo-de-palma (Acessado em 10 de JULHO de 2017)

MACEDO, C. O. \& SOUSA, R. B. Novos projetos, velhas práticas: os impasses entre agricultura camponesa e agronegócio do dendê em terras amazônicas. In: MACEDO, C. O. et. al (Orgs). Os "nós” da questão agrária na Amazônia. Belém: Editora Açaí, 2016.

MCMICHAEL, P. Regimes alimentares e questões agrárias. São Paulo; Porto Alegre: Editora Unesp; Editora da UFRGS, 2016.

NAHUM, J. S.; BASTOS, C. S. Do sítio camponês ao lote de dendê: transformações do espaço rural na Amazônia paraense no século XXI. Revista NERA (UNESP), v. 37, 2017, p. 54-76.

OLIVEIRA NETO, A. C. Territórios subordinados: análise da política de desenvolvimento territorial a partir da produção de óleo de palma pela Agropalma em assentamentos de reforma agrária no Pará. Presidente Prudente: UNESP [s.n], 2017. (Tese de doutorado).

PALMA DE ÓLEO. PARÁ2030. Disponível em: http://para2030.com.br/oportunidades/oleode-palma/ (Acessado em 29 de setembro de 2017) 
PARÁ. Pará 2030. Disponível em: http://para2030.com.br/oportunidades/oleo-de-palma/ (Acessado em 6 de outubro de 2016).

RAMALHO FILHO, A. \& MOTA, P. E. F. Contexto e objetivos do Zoneamento Agroecológico para a cultura da palma de óleo nas áreas desmatadas da Amazônia. In: RAMALHO FILHO, A. et al. (ORGs.). Zoneamento agroecológico, produção e manejo da cultura de palma de óleo na Amazônia. Rio de Janeiro: Embrapa Solos, 2010.

SAF-BIODIESEL. MDA. Disponível em: MDA: www.mda.gov.br/sitemda/secretaria/safbiodiesel/sobre-o-programa (Acessado em 29 de setembro de 2017)

SVAMPA, M. Extrativismo e neodesenvolvimentista: um giro ecoterritorial rumo a novas alternativas? In: DILGER, G. et al (ORGs.). Descolonizar o imaginário: debates sobre pós-extrativismo e alternativas ao desenvolvimento. Traduzido por Igor Ojeda. São Paulo: Fundação Rosa Luxemburgo, 2016.

SOUSA, R. B. Pelas margens do Igarapé Arapiranga: o processo de territorialização camponesa no Município de Concórdia do Pará. UFF/PPGEO. Niterói: 2014. (Dissertação de mestrado)

ZIBECHI, R. El estado de excepción como paradigma político del extractivismo. In: COMPOSTO, C. \& NAVARRO, M. L. (Compiladoras). Territorios en disputa. Despojo capitalista, luchas en defensa de los bienes comunes naturales y alternativas emancipatorias para América Latina. -1를 ed.- México, D. F.: Bajo Tierra Ediciones, 2014.

\section{NOTAS DE AUTOR}

\section{CONTRIBUIÇÃO DE AUTORIA}

Rafael Benevides de Sousa - Concepção. Coleta de dados, Análise de dados, Elaboração do manuscrito, revisão e aprovação da versão final do trabalho

Cátia Oliveira Macedo - Concepção e elaboração do manuscrito. Coleta de dados Participação ativa da discussão dos resultados; Revisão e aprovação da versão final do trabalho.

\section{FINANCIAMENTO}

Não se aplica.

\section{CONSENTIMENTO DE USO DE IMAGEM}

Não se aplica

\section{APROVAÇÃO DE COMITÊ DE ÉTICA EM PESQUISA}

Não se aplica.

\section{CONFLITO DE INTERESSES}

Não se aplica

\section{LICENÇA DE USO}

Este artigo está licenciado sob a Licença Creative Commons CC-BY. Com essa licença você pode compartilhar, adaptar, criar para qualquer fim, desde que atribua a autoria da obra.

\section{HISTÓRICO}

Recebido em: 01-02-2019

Aprovado em: 06-02-2019 